\title{
Effect of Methanol Extract of Carica papaya Seed on Some Hormone Function in Male Albino Rats
}

\author{
Reuben A. ${ }^{1}$, Wurochekke A. U. ${ }^{2,3}$, Mahmoud S. J. ${ }^{3}$ \\ Department of Biochemistry, Modibbo Adama University of Technology, Yola, Adamawa State, Nigeria
}

\begin{abstract}
In this study, the anti-fertility activity of the methanolic seed extract of Carica papaya was investigated. Phytochemical screening of crude extract revealed the presence of alkaloids, flavonoids, glycosides, saponins and tannins while anthraquinone and phlobatannins were found to be absent. The study was conducted on 25 healthy male albino rats following oral administration of 100 $\mathrm{mg} / \mathrm{kg}$ body weight, $200 \mathrm{mg} / \mathrm{kg}$ body weight, $400 \mathrm{mg} / \mathrm{kg}$ body weight and $800 \mathrm{mg} / \mathrm{kg}$ body weight methanolic seed extract for the period of 7days. Epididymidal sperm count, total motility and viability, serum testosterone, luteinizing hormone, follicle stimulating hormone and prolactin were studied. There was a significant $p<0.05$ reduction in sperm counts and viability, testosterone and luteinizing hormone as compared to the control group. While there was elevated serum level of follicle stimulating hormone and Prolactin as compared to the control group. These results suggest that methanolic seed extract of Carica papaya posses anti-fertility activities which could impair spermatogenesis, hormonal synthesis and other functions which might lead to infertility.
\end{abstract}

Keywords: Carica papaya, Phytochemical screening, Anti-fertility activity, Hormones, Male rats.

\section{Introduction}

Fertility is the ability to become pregnant and generate offspring. Anti-fertility agents induce inability to conceive and produce offspring. Several plant products inhibit male fertility and may be developed into contraceptive. Even though, many indigenous plants have shown to prevent the birth, only few plants have so far been investigated for antifertility (Chowdhury et al., 2001, Kamal, 2003).

The importance of plants as a source of anti-fertility drugs has been emphasized by many researchers (Oderinde et al., 2002, McNeil et al., 2003, Olabiyi et al., 2006). Antifertility agents obtained from indigenous medicinal plants would be of immense benefit especially to inhabitants of developing countries, since the cost of these drugs would be within their means.

Therefore, this study was to investigate the anti-fertility activity of the seed extract on some functions in male rats.

\section{Materials and Method}

\section{Plant}

Cariaca papaya seed was bought from Jimeta Modern Market, Yola, Adamawa State and was authenticated by a Botanist at the Department of Plant Science Modibbo Adama University of Technology, Yola.

Experimental Animals.

A total number of 25 male wister rats weighing between 90$110 \mathrm{~g}$ were purchased from National Veterinary Research Institute, Vom, Nigeria. The animals were housed in a plastic cage and allowed to acclimatize and feed with standard diet and water ad-libitum.

\section{Plant Extraction}

Fresh seeds of Carica papaya was allowed to dry at room temperature under shed, dried seed was made into powder using mortar and pestle where $200 \mathrm{~g}$ of the dried sample was extracted with $80 \%$ aqueous methanol over 24 hours period . The extract was then filtered using a filter paper (Whatmann
No.1) and concentrated using water bath at $40^{\circ} \mathrm{C}$ ( Lohiya et al., 2006).

\section{Treatment}

Twenty five adult male albino rats weighing between 120$150 \mathrm{~g}$ were divided into 5 groups, $(\mathrm{n}=5)$. Group 1 received normal diet which served as control group, group 2, 3, 4 and 5 were administered daily with doses of 100, 200, 400 and $800 \mathrm{mg} / \mathrm{kg}$ body weight for 7 days respectively following the method of Udoh, (2007). The rats were anaesthetized at the time of sacrifice by placing them in inhalation Jar soaked with chloroform in sealed cotton wool. Epididymal spermatozoa were collected and blood sera were prepared for hormonal assays.

\section{Hormonal Assays}

Serum sample were assayed for testosterone, luteinizing hormone, Follicle stimulating hormones and prolactin. The method used was Microwell enzymes-linked immunoassay (ELISA) using analytical grade reagent (Syntron bioresearch Inc. following the instructions provided by manual).

\section{Statistical Analysis}

Values obtained were expressed as mean \pm SEM and data were analysed using ANOVA with multiple comparison versus control group with the help of SPSS version 20 . The values $\mathrm{P}<0.05$ was considered significant (Duncan et al. 1997).

\section{Results and Discussion}

The results in table 1 shows the phytochemical components detected in the seed sample of Carica papaya, alkaloids, saponins, phenols, flavoroids and glycosides were present while anthraquinone and phlobatannins were absent. 


\section{International Journal of Science and Research (IJSR) \\ ISSN (Online): 2319-7064}

Index Copernicus Value (2013): 6.14 | Impact Factor (2014): 5.611

Table1: Some phytochemical components of Carica papaya seed extract.

\begin{tabular}{|lc|}
\hline Phytochemical components & Seed \\
\hline Alkaloids & + \\
Anthraquinone & - \\
Flavonoids & + \\
Phlobatannins & - \\
Phenols & + \\
Glycosides & + \\
Saponins & + \\
Tannins & + \\
\hline
\end{tabular}

Key: + present of phytochemical components

- Absent of phytochemical components
Table 2 revealed a significant decrease $p<0.05$ in sperm count and viability in all groups treated with various doses of Carica papaya seed extract. However, the total mobility remains significantly increased $\mathrm{p}<0.05$ in $400 \mathrm{mg} / \mathrm{kg}$ body weight and $800 \mathrm{mg} / \mathrm{kg}$ body weight compared to the normal control group

Table 2: Effects of Carica papaya seed extract on sperm parameters.

\begin{tabular}{|l|l|l|l|}
\hline Treatments & Sperm count $\left(X^{\prime} 0^{\wedge}\right.$ 6) & Total motility (\%) & Viability(\%) \\
\hline Normal control & $14.05 \pm 0.35$ & $32.50 \pm 0.5$ & $61.00 \pm 2.00$ \\
\hline $100 \mathrm{mg} / \mathrm{kg}$ bwt & $13.30 \pm 0.10^{*}$ & $29.00 \pm 0.8$ & $54.00 \pm 4.00$ \\
\hline $200 \mathrm{mg} / \mathrm{kg}$ bwt & $11.20 \pm 0.10^{*}$ & $44.50 \pm 11.5$ & $28.55 \pm 1.55^{*}$ \\
\hline $400 \mathrm{mg} / \mathrm{kg}$ bwt & $10.20 \pm 0.90^{*}$ & $60.50 \pm 0.5^{*}$ & $13.15 \pm 0.15^{*}$ \\
\hline $800 \mathrm{mg} / \mathrm{kg}$ bwt & $8.35 \pm 1.05^{*}$ & $60.00 \pm 0.50^{*}$ & $49.00 \pm 1.90^{*}$ \\
\hline
\end{tabular}

Values are expressed as mean \pm SEM $(n=5)$, bwt - body weight.

Key: * significantly decreased as compared with normal control group $p<0.05$

\# significantly increased as compared with normal control group $\mathrm{p}<00.05$

The results from table 3 shows that there is significant decrease $\mathrm{p}<0.05$ in serum testosterone $(\mathrm{T})$ and luteinizing hormone (L) in treated groups as compared to control group but there is significant $\mathrm{p}<0.05$ increase in serum follicle stimulating hormone (FSH) and prolactin (PRL) in treated groups as compared to control group.

Table3: effects of Carica papaya seed on some hormones.

\begin{tabular}{|l|l|l|l|r|}
\hline Treatment & $\mathrm{T}(\mathrm{ng} / \mathrm{kg})$ & $\mathrm{LH}(\mathrm{N} / \mathrm{ml})$ & FSH(N/ml) & PRL(ng/ml) \\
\hline Normal control & $3.5 \pm 0.37$ & $1.60 \pm 0.13$ & $1.034 \pm 0.03$ & $0.81 \pm 0.05$ \\
\hline $100 \mathrm{mg} / \mathrm{kg}$ bwt & $2.80 \pm 0.13$ & $0.97 \pm 0.05^{\mathrm{a}}$ & $1.64 \pm 0.08^{\mathrm{b}}$ & $9.40 \pm 0.16$ \\
\hline $200 \mathrm{mg} / \mathrm{kg}$ bwt & $1.63 \pm 0.19^{\mathrm{a}}$ & $0.74 \pm 0.03^{\mathrm{a}}$ & $1.98 \pm 0.08^{\mathrm{b}}$ & $11.90 \pm 0.22^{\mathrm{b}}$ \\
\hline $400 \mathrm{mg} / \mathrm{kg}$ bwt & $0.52 \pm 0.90^{\mathrm{a}}$ & $0.51 \pm 0.07^{\mathrm{a}}$ & $2.24 \pm 0.15^{\mathrm{b}}$ & $12.50 \pm 0.03^{\mathrm{b}}$ \\
\hline $800 \mathrm{mg} / \mathrm{kg}$ bwt & $0.25 \pm 0.01^{\mathrm{a}}$ & $0.23 \pm 0.0$ & $2.00 \pm 0.08^{\mathrm{b}}$ & $14.21 \pm 0.03^{\mathrm{b}}$ \\
\hline
\end{tabular}

Values are expressed as mean \pm SEM ( $=5)$,bwt - body weight.

Key: ${ }^{a}$ significantly deceased as compared to control group $\mathrm{p}<0.05$

${ }^{\mathrm{b}}$ significantly increased as compare to control group $\mathrm{P}<0.05$

\section{Discussion}

The presence of alkaloids, flavonoids, tannins, saponins, glycosides and phenols has been revealed by the study as the phytochemical components in the Carica papaya seed. These various phytochemicals detected in Carica papaya seeds are known to have beneficial uses and exhibit physiological activity (Adeneye et al., 2006).

The study has demonstrated a significant decrease in sperm count and viability of the treated rats with methanolic extract. This decrease in sperm count and viability could be attributed to the action of the extract which could target the internal milieu of the epididymis (Hucynh et al., 2006)

The exert mechanism by which Carica papaya seed reduced sperm count and viability is not known, but it has been suggested that the compound papain may cross the blood testis barrier to exert harmful effects on control of the seminiferous tubules of the testes (Oyekunle and Omope, 2010).
The study has demonstrated a significant decrease in the serum level of testosterone of the treated groups as compared to the control group. This observation was similar to the earlier findings of Udoh et al., 2005, Udoh and Ekpenyong, 2001. The reduction in the serum level of testosterone could be probably be due to the decrease of serum levels of LH observed in this study.

Leydig cells secrete testosterone by the stimulation effect of luteining hormone (Udoh and Udoh, 2005, Udoh et al., 2005, Udoh et al., 2005) and follicle stimulating hormone induces spermatogenesis in the seminiferous tubules (Sharpe, 1994). In males, reduction of testosterone level might impair spermatogenesis and cause male infertility.

This study further observed an increase in serum prolactin level in treated groups as compared to the control group. Prolactin also associated primarily with male infertility. Acute hyperprolactinemia is known to suppress testosterone 


\section{International Journal of Science and Research (IJSR) \\ ISSN (Online): 2319-7064}

Index Copernicus Value (2013): 6.14 | Impact Factor (2014): 5.611

synthesis and male fertility through prolactin induced hypersecretion of gonadotropin releasing hormone (GnRH) through prolactin receptors on hypothalamic dopaminergic neurons (Albertson et al., 1987., Bartke et al., 1986). However, prolactin has also been reported to play role in the synthesis of testosterone (Gill-sharma, 2009).

\section{Conclusion}

It is therefore reasonable to suggest that the results clearly demonstrate that short term administration of Carica papaya seed extract which provides beneficial anti-fertility effects on male albino rats and have inhibited the hormonal regulation of spermatogenesis indicating infertility.

In this regard, this Carica papaya seed extract have shown great promise in the quest for safer, cheaper and alternative method of regulating fertility in male which might be useful to the health professionals, scientists, and scholars working the field of pharmacology and therapeutics to develop evidence based male contraceptive in man and animal model. However, knowledge on the specific modes of action of the seed extract to exerts anti-fertility effects is not fully understood, but studies have shown that most of the seed plant have been found to contain substances like alkaloids, glycosides, tannins, flavonoids and saponins that are frequently implicated as having anti-fertility effects.

\section{References}

[1] Adeyeye, A .A., Ajagbonna, O. P., Adeleke, T. I., and Bello, S. O. (2006). Preliminary toxicity and phytochemical studies of the seed extracts of Carica papaya in rats. Ethnopharmacology 105:374-379.

[2] Albertson, B. D., Siekiewicz, M. L., Kimball, D., Munabi, A. K.,Cassoria, F., and Loriaux, D. L.(1987). New evidence for a direct effect of prolactin on rat adrenal steroidogenesis. Endocrine Research 13(3) : 317-333

[3] Bartke, A., Paulsen, J. D.,Negro-vilar, A., Lucina, E., and Martinez- Garcia, C. (1986). Hyperprolactinemia and male reproduction, in andrology. Male fertility and sterility. Eds., Academic press, New York, NY, USA. 101-123.

[4] Chowdhury, S. R., Gupta, C. M., and Kamboj, V. P. (2001). Current status in fertility regulation: indigenous and modern approaches. Asian Journal of Andrology. Pp 99-119.

[5] Duncan, R. C., Knapp, R. G. and Miller, M. C. (1977). Test of hypothesis in population: introductory biostatistics for the health sciences. John wiley and sons Inc. NYPP 71-96.

[6] Gill-Sharma, M. K. (2009). Prolactin and male fertility: The long short feedback Regulation. Internal Journal of Endocrinology.13.

[7] Huynh, P. N., Sinha-Hikim, A. P., Wang, C., Stetonovic, K., Lue, Y. H., Leung, A., et al., (2000) Long term effects of triptolide on spermatogenesis, epididymal sperm function, and fertility in male rats. Journal of Andrology. 21: 689-99

[8] Kamal, R., Gupta, R., S., Lohiya, N. K. (2003). Plants for male fertility regulation phytotherapy Research $17: 579-90$
[9] Lohiya, N. K., Man, Vannan, B., and Garg, S. (2006). Toxicological investigation on the methanol subfraction of seed of Caricapapaya as a male contracption in albino rats. Reproductive Toxicology, 22:461-468.

[10] McNeil, R. I., Noronha, C. C., Kasemija, I. O., OKanlawon, A. O. (2003). The anti-ovulatory effect of a seed extracts of RicinascomminusL. Nigerian postgraduate medical journal. 2:31-34.

[11] Oderinde, O., Noroba, C., Oremosu, O. A. (2002). Abortifacient properties of aqueous extract of Caricapapaya seeds on female Sprague-Dawley rats. Nigerian postgraduate medical Journal 9:95-98.

[12] Olabiyi, O. A., Oremosu, A. A., Noronha, C.O., Okanlawon, A. A. (2006).Effects of cotton seed oil (Gossypol spp)and cotton seed mealon estrous cycle, ovulation and histoarchitecture of female cycle, ovulation and histoarchitecture of female reproductive organs of adult cyclic sprague-Dewley rats. Nigerian postgraduate medical Journal 5:21-26.

[13] Oyekunle, O. A. and Omope, M. M. (2010).Evaluaion of andrological induces and testicular histology following chronic administration of methanol extract of Carica papaya seed in rats. African Journal of pharmaceutical pharmacology, Volume 4 issues, PP.252-255.

[14] Sharpe, R .M. (1994). Regulation of spermatogenesis., inyhephysiology of reproduction (eds., knobil and J. D. Neil), NY: Ravenpress, New York, 1363-1434.

[15] Udoh, p., Essien , I. and Udoh, F. (2005a). Effects of Caricapapaya seeds extract of the morphology of pituitary-gonadal axis of male albino rats. Phytotherapy Research 19:1065-1068.

[16] Udoh, F. V and Udoh, P. B. (2005b). Hepatotoxicity of the methanol extracts of Carica papaya seedsin wistar rats. Pharmaceutical Biology 43(40):349-352

[17] Udoh, F. V.,Udoh, P. B. and Umoh, E. E. (2005c). Activity of alkaloids extract of Carica papaya seeds on reproductive functions in male wistar rats. Pharmaceutical Biology. 43(6) : 563-367.

[18] Udoh, F. V.(2007). The effects of Gnetumafricanum leaf extracts on some biochemical induces and endocrine functions in albino rats. A Ph.D. Thesis, university of Calabar, Calabar Nigera.

[19] Udoh, P. and Ekpeyong, J. ( 2001) Effects of Mucunaurens (horse eye bean) on the gonads of male GuineaPigs. Phytotherapy Research15:99-102.

[20] Vongtau, H. O., Abbah, J., chindo, B. A., Mosugu, ., Salawa, A. O. and Kwanashie, H. O. (2005). General inhibitory effects of the methanol extract of Neorautanoniamitis root in rats and mice. Journal of pharmacology and Biology 43:113-120. 